\title{
Do Investors See the Darkness in Narcissism?
}

\author{
Anis Triki* \\ Assistant Professor \\ College of Business Administration \\ The University of Rhode Island \\ Kingston, RI 02881 U.S.A. \\ trikianis@uri.edu \\ Phone: 401-874-2387 \\ Gilberto Marquez-Illescas \\ Assistant Professor \\ College of Business Administration \\ The University of Rhode Island \\ Kingston, RI 02881 U.S.A. \\ gmarquez@uri.edu \\ Phone: 401-874-5409
}

Acknowledgement: We thank Laura Trainer for her help.

*Corresponding Author

PLEASE DO NOT SHARE OR DISTRIBUTE WITHOUT THE AUTHORS' PERMISSION. 


\title{
Do Investors See the Darkness in Narcissism?
}

\begin{abstract}
We explore whether the impact of favorable financial disclosures on investors' judgment and decision making is contingent on their perception about CEOs' narcissism. Specifically, our theoretical model predicts that CEOs' narcissism impact investors' willingness to invest through their perceptions of management credibility and disclosure credibility. Using data from 153 nonprofessional investors, we provide support to those predictions. First, we find that investors' perception of management credibility is lower when a more narcissistic CEO leads the company. Second, our results indicate that this lack of credibility reduces investors' perception of disclosure credibility, which leads to a lower willingness to invest. Based on this evidence, we conclude that CEOs' narcissism reduces the effect that reporting good news may have on investors' willingness to invest. In other words, we document that CEOs' narcissism exerts an indirect negative effect on investors' reactions (i.e., willingness to invest) to good news reported by a company.
\end{abstract}

Key Words: Management Credibility, Disclosure Credibility, Narcissism, Investors, Willingness to Invest, CEO.

\section{Introduction}

Due to the substantial growth of communication technologies, investors' nowadays have access to a much higher amount of information than they used to. For example, social media allows investors to share and access others' opinions, and receive different types of information in a timely manner. In such an environment, qualitative information about companies and their CEOs spreads much faster and covers a wider audience than it used to. Likewise, several media outlets are sharing information about favorable CEO traits such as the Forbes article entitled "7 Personality Traits Every CEO Should Have" (Patel 2017). In this article, we explore the extent to which qualitative information about CEOs' personality influences investor's reactions to firms' corporate disclosures. Specifically, we propose that investors will question the credibility of positive corporate disclosures (i.e., reporting good news) coming from companies led by a more narcissistic CEO. As a result of this lack of credibility, we posit that the influence of a company's positive (i.e., reporting good news) corporate disclosures on investors' willingness to invest will be lower when the company is led by a more narcissistic CEO. 
Do Investors See the Darkness in Narcissism?

The term narcissism refers to a complex personality trait that includes an inflated view of self, intrapsychic and interpersonal strategies to maintain this grandiose self-image, as well as poor relational functioning and exploitative behavior (e.g., Morf and Rhodewalt 2001; Twenge and Campbell 2003). Narcissism is perceived as a construct that has mostly negative implications for the individual (Campbell 2001), and is classified as one of the dark triad of personality traits together with psychopathy and Machiavellianism (Jones and Paulhus 2014). Consistent with this overly negative conceptualization of narcissism, findings from academic literature in different business areas suggest that CEO narcissism may have undesirable consequences on different aspects of firm level outcomes such as firm performance (Chatterjee and Hambrick 2007, 2011; Olsen, Dwokis, and Young 2014; Ham, Seybert, and Wang 2018), financial reporting (e.g., Major 2016, Ham et al., 2018; Marquez-Illescas, Zebedee, and Zhou 2019), tax reporting strategies (Olsen and Stekelberg 2016), litigation risk (Rijsenbilt and Commandeur 2013; O’Reilly III, Doerr, and Chatman 2018), or audit risk and costs (Johnson, Kuhn, Apostolou, and Hassell 2013).

The notions provided by prior academic business research have made its way to popular business press and media, where it is somehow common to find articles highlighting the potential negative effects that CEO narcissism may have on firm level outcomes. For instance, article titles such as "How narcissistic CEOs put companies at risk" (Sahadi 2018), "Can a Narcissistic CEO destroy their company” (Beheshti 2018), “Are narcissistic CEOs bad for business?” (Wood 2018), "Narcissistic CEOs are more destructive than you think" (INSEAD Knowledge, 2014), "Narcissistic CEOs tend to have larger legal bills" (Nordqvist 2018) or "Narcissistic CEOs Weaken Collaboration and Integrity" (Savchuk 2019), are examples of how business media have spread the notion that CEO narcissism is something that could potentially go against investors' best interest. Likewise, beyond this kind of informative articles about the general consequences of 
Do Investors See the Darkness in Narcissism?

CEO narcissism, business press has also provided insights about the level of narcissism of some specific CEOs. For instance, Jackson (2013), in Forbes, published an article entitled: “The Top 25 Most Narcissistic CEOs In Tech", and the Washington Post published an article titled "The least narcissistic American CEOs” (Mcgregor 2013).

As suggested by the prior notions, CEO narcissism is likely to have a bad reputation among business researchers and practitioners. However, prior studies fall short on providing insights about whether CEO narcissism may have reputational consequences on investor's reaction to firms' disclosures. In this manuscript, we fill this gap by arguing that CEOs' narcissism has a negative effect on investors willingness to invest, and that this effect is sequentially mediated by investors' perceptions of management credibility and disclosure credibility. Specifically, we use Mercer's (2004) framework to predict that CEOs' narcissism decreases investors' perception of management's credibility, which in turn reduce their perceptions of disclosure credibility, and ultimately, their willingness to invest. Because investors are those who process the information available in the market, we consider that understanding how CEO narcissism impacts investors' decisions is equally important than understanding how narcissism impacts managers' decisions.

We test out theoretical predictions using data from 153 non-professional investors collected thorugh Amazon Mechanical Turk. In our experimental design, participants had to decide how much money to invest in a fictitious company that is reporting a good financial performance. Similar to the literature exploring the effect of CEO reputation (e.g., Cianci and Kaplan 2010), we manipulated subjects' perception of CEO narcissism by providing them with a press article in which an independent source ranks the CEO of the fictitious company to be more or less narcissistic. Consistent with our theoretical expectations, results show that investors perceive more narcissistic CEOs to be less credible and this makes investors reluctant to believe in the CEO's 
Do Investors See the Darkness in Narcissism?

disclosures. As a result of these lack of credibility on the reported corporate information, investors are less willing to invest in companies managed by narcissistic CEOs, even when they report a positive financial outlook.

We consider that our study makes a number of contributions that may be interesting for both researchers and practitioners. From the research perspective, we provide a theoretical model that depicts the specific channel through which CEO narcissism influence investors' reaction to corporate disclosures. Specifically, we demonstrate that the effect of "CEO's narcissism reputation" on investors' decisions flows sequentially through management's credibility and disclosure credibility. ${ }^{1}$ Previous studies investigating different determinants of investors' judgment and decision making have focused on either management credibility (e.g., Trinkle, Crossler, and Bélanger 2015) or disclosure credibility (e.g., Grant, Hodge, and Sinha 2018; Triki and Arnold 2016), as well as on the mediating role of disclosure credibility (e.g., Triki 2019). We go one step beyond this prior work by proposing a sequential mediation model that encompasses the mediating role of both management credibility and disclosure credibility. As stated by Mercer (2004), "Mach of the accounting literature treats "disclosure credibility" as synonymous with "management credibility", but there are important differences between these concepts" (p. 186). Concretely, our model shows that investors perceive more narcissistic CEOs to be less credible. This lack of credibility on the CEO dampens investors' credibility on good news reported by companies. Overall, this CEO narcissism-driven lack of credibility on corporate disclosures seems to reduce the influence that reporting good news may have on investors' willingness to invest. In this matter, our work complements prior literature using the "affect-as-information"' theory (e.g.,

\footnotetext{
${ }^{1}$ Mercer (2004) defines Management credibility as “....investors' perception of managers' competence and trustworthiness (cf., Hovland et al. 1953, 21)" and disclosure credibility as "investors' perceptions of the believability of a particular disclosure" (Mercer 2004 p. 186)
} 
Do Investors See the Darkness in Narcissism?

Elliot, Hodge, and Jackson 2014) to explain investors' reaction to the positive or negative news provided by corporate reports (e.g., CSR reports). We document that investors' reaction to information is driven not only by the affect that the information disclosed by firms may generate, but also by their perception about the credibility of the CEO. We show that investors link the credibility of corporate disclosures to CEO's personality traits such as narcissism. This finding contributes to the research stream exploring the influence of CEO's personality on market perceptions and shareholder behavior (e.g., Harrison, Thurgood, Boivie, and Pfarrer 2019). Specifically, this study expands the current knowledge about the effect of CEO narcissism on capital markets. Our findings suggest that CEO narcissism might have an immediate negative reputational effect on investors' preferences that does not appear necessarily as a result of the effect of CEO narcissism on firm-level outcomes. Keeping everything else constant, if investors are presented with a choice to invest in two identical companies, they will be more likely to allocate their resources to a company managed by a less narcissistic CEO.

From a practical perspective, evidence indicates that investors do not perceive narcissism as a positive trait in CEOs. Investors' perceive corporate disclosures coming from narcissistic CEOs as less credible, and this lack of credibility reduce their willing to invest. This is consistent with prior work suggesting that a lack of credibility on corporate disclosures may reduce firm returns both, in the short and long term (e.g., Ng, Tuna, and Verdi 2013). Corporate disclosures are one of the main tools that companies have to satisfy investors' information needs and reduce their uncertainty about the future performance of the company. Our findings indicate that CEO narcissism causes an immediate negative "image effect" that impairs the firm's capacity to influences investors' behavior through corporate disclosures. Moreover, this lack of credibility driven by CEO narcissism is likely to make a company less attractive to potential and current 
investors, even if the company is reporting a favorable economic outlook. Therefore, CEOs' "narcissistic image" may actually represent a threat for the market value of the company. From a practitioner or management perspective, our results indicate that firms should be at least aware of this potential effect when hiring their CEOs. Also, firms should constantly monitor CEOs' behavior and media exposure, and take actions to prevent CEOs from becoming known for their narcissism.

\section{Literature Review and Hypothesis}

Narcissism is probably one of the most discussed personality traits in business literature in recent times (Young, Du, Dworkis, and Olsen 2016). The term narcissism refers to a complex personality trait that includes an inflated view of self, intrapsychic and interpersonal strategies to maintain this grandiose self-image, as well as poor relational functioning and exploitative behavior (e.g., Morf and Rhodewalt 2001; Twenge and Campbell 2003). ${ }^{2}$ As stated by Olsen et al. (2014, 245) "Narcissists have a strong desire for recognition, affirmation, and praise (Resick, Whitman, Weingarden, and Hiller 2009) and can be reckless in pursuing self-enhancement opportunities (Campbell, Reeder, Sedikides, and Elliott 2000; Wallace and Baumeister 2002)”.

Prior research generally relies on the upper echelon theory to explain the influence of CEO narcissism on different firm-level outcomes. ${ }^{3}$ Although some prior studies suggests that CEO

\footnotetext{
${ }^{2}$ Narcissism is considered a continuous personality dimension (e.g., Emmons 1987; Chatterjee and Hambrick 2007), and individuals may present different levels of narcissism without being diagnosed as mentally ill (Young et al. 2015). As a matter of fact, all humans present some signs of narcissistic behavior (e.g., Amernic and Craig 2010). In the extreme of this continuous dimension are individuals diagnosed with a mental pathology (i.e., Narcissistic Personality Disorder or NPD). Business literature, including our study, explores the effects of non-clinical narcissism.

${ }^{3}$ Recent literature also explores the effect that other personality traits of CEOs, such as humility (Zhang, Ou, Tsui, and Wang 2017; Ou, Waldman, and Peterson 2018), psychopathy (Boddy 2017), overconfidence (Galasso and Simcoe 2011; Kuang, Moham, and Qin 2015; Hsieh, Wang, and Demirkan 2018), extraversion and openness (Araujo-Cabrera, Suarez-Acosta, and Aguiar-Quintana 2016; Becker, Medijedovic, and Merkle 2019), emotional intelligence (Azouzi and Jarboui 2017), or Hubris (Tang, Qian, Chen, and Shen 2015; Park, Kim, Chang, Lee, and Sung 2018) have on a wide range of firm outcomes (e.g., performance, voluntary disclosure, leadership, cost management, etc.). For a general summary of prior research on this area, see Smith, Hill, Wallace, Recendes, and Judge (2018).
} 
Do Investors See the Darkness in Narcissism?

narcissism may influence firm performance in a positive way, ${ }^{4}$ most of these prior studies provide an unfavorable perspective about the consequences of CEO narcissism on different firm-level decisions and outcomes. In this matter, prior work suggests that companies led by more narcissistic CEOs are more likely to be sued by investors (O'Reilly III et al. 2018), over-invest and exhibit lower financial productivity (Ham et al. 2018), , commit fraud (Rijsenbilt and Commandeur 2013), use more aggressive tax strategies (Olsen and Stekelberg 2016), choose riskier or bolder business strategies (i.e., Chatterjee and Hambrick 2007, 2011), reduce employees' motivation to behave entrepreneurially (Engelen, Neumann, and Schmidt 2016), have higher audit risk, and pay higher audit fees (Johnson et al. 2013).

In terms of the effect of top executives' narcissism on corporate disclosures, past studies indicate that CEO narcissism is likely to have a negative impact on different aspects of corporate disclosures. For example, firms led by a more narcissistic top executives are more likely to use more aggressive earnings estimates (Major 2016), report lower quality financial information (Ham, Lang, Seybert, and Wang 2017), or use a more positive tone (Marquez-Illescas et al. 2018). Based on these findings, one might assume that rational investors may have reasons to question the credibility of the financial disclosures of firms led a narcissistic CEO. However, to our best knowledge, there is not any theoretical or empirical work exploring this matter. In this manuscript, we try to fill this gap by exploring whether non-professional investors' knowledge about CEO narcissism affect their willingness to invest in a company reporting a positive financial outlook. ${ }^{5}$ Specifically, we propose that investors' credibility on the good news reported by a company will

\footnotetext{
${ }^{4}$ For instance, in terms of Earnings Per Share (EPS) and stock prices (Olsen et al. 2014), corporate social responsibility reporting practices (Petrenko, Aime, Ridge, and Hill 2016), or the adoption of discontinuous technologies (Gerstner, König, Enders, and Hambrick 2013).

${ }^{5}$ In this regard, we investigate the case when investors are informed about CEO narcissism by a third party (i.e., press article).
} 
Do Investors See the Darkness in Narcissism?

decrease when they have some information indicating that the company's CEO is highly narcissistic. As a result of this lack of credibility driven by CEO narcissism, we posit that investors will be less willing to invest in the company, even if it issues a positive corporate report.

Prior research provides some evidence suggesting that non-professional investors are likely to perceive CEO narcissism as "negative". In this regard, Rauthmann and Kolar (2012) compared lay people perception of narcissism to each of the other two traits of the dark triad: psychopathy and Machiavellianism. Findings from their study suggest that narcissism is the brightest (less dark) trait among the dark triad. However, despite its relative brightness to the other two dark traits, on its own, it remains a dark trait that is perceived as undesirable. Other research indicates that, initially, narcissists might be charming (Back, Schmukle, and Egloff 2010) and look very motivated (Furtner, Rauthmann, and Sachse 2011), which makes people interacting directly with them to have a favorable first impression about them. However, this perception tends to deteriorate over time as people get to know them better (Malkin, Zeigler-Hill, Barry, and Southard 2013). In other words, once individuals realize that someone is highly narcissistic, they tend to have an unfavorable opinion about that person. These prior studies suggest that non-professional investors are likely to perceive CEO narcissism as undesirable. In the same vein, we consider that this negative perception may be reinforced by popular business press, which commonly highlights the potential negative effects of CEO narcissism on firm outcomes (e.g., Blanding 2018; INSEAD Knowledge 2014; Jackson 2012). For instance, article titles such as "How narcissistic CEOs put companies at risk" (Sahadi 2018), "Can a Narcissistic CEO destroy their company" (Beheshti 2018), “Are narcissistic CEOs bad for business?” (Wood 2018), "Narcissistic CEOs are more destructive than you think" (INSEAD Knowledge 2014), or "Narcissistic CEOs tend to have larger 
Do Investors See the Darkness in Narcissism?

legal bills" (Nordqvist 2018), are examples of how business media has spread the notion that CEO narcissism is something that could potentially deteriorate investors' returns.

Consistent with the prior arguments, some research suggests that investors are likely to see CEO narcissism as something particularly negative when evaluating the information contained in corporate disclosures. Hoffman et al. (2013) investigates the effect of leaders' narcissism on followers' perceptions of leaders' effectiveness across low and high ethical contexts. Their findings suggest that followers view narcissistic leaders as unethical and ineffective in highly ethical contexts only. The disclosure of corporate information is a business context in which market agents (i.e., investors, creditors, regulatory agencies, etc.) demand firms to be ethical when disclosing information. In this context, CEOs are supposed to communicate reliable and truthful information in a timely manner to external stakeholders, so they can allocate their resources in the most efficient way. Because corporate disclosures require a highly ethical behavior from CEOs, we expect non-professional investors to perceive narcissism as a personality trait that may reduce CEOs' effectiveness to disclose useful and truthful information. Therefore, we expect CEO narcissism to reduce investors' perception of disclosure credibility.

In general, the extent to which a particular corporate disclosure can change investors' decisions is contingent on investors' favorable perception of the believability of such disclosure (Mercer 2004; Grant et al. 2018). Prior literature on this matter suggests that the extent to which investors may judge a communication to be credible is determined by their perception about the credibility of the source of the message (Mercer 2004). In other words, investors asses the credibility of the source to assess the credibility of the message. Given that financial disclosures of companies are communicated by management (i.e., CEOs), investors may address the credibility of the information communicated in financial disclosures by assessing the credibility of 
Do Investors See the Darkness in Narcissism?

the management of the company. In this regard, investors' perceptions of management credibility of a company's CEO is likely to be determined by their combined perception of CEOs' competence and trustworthiness (Hovland, Janis, and Kelly 1953; Mercer 2004; Mercer 2005; Barton and Mercer 2005; Koonce and Lipe 2010; Krische, Sanders, and Smith 2014; Trinkle, Crossler, and Bélanger 2015). Since, as above mentioned, prior literature suggests that individuals view narcissistic leaders as ineffective and unethical in highly ethical contexts (Hoffman et al. 2013), we predict that CEOs' narcissism will have a negative impact on investors' perception of management credibility.

Once investors assess the credibility of the source (management's credibility), they use this information to assess the credibility of the message (disclosure credibility). Mercer $(2004,186)$ defines disclosure credibility as “...investors" perception of the believability of a particular disclosure" and argues that higher management credibility should lead to a higher perception of disclosure credibility. ${ }^{6}$ Based on Mercer's (2004) theoretical framework, we expect management credibility to have a positive effect on investors' perception of disclosure credibility. Concretely, we posit that the negative impact that CEO narcissism has on investors' perception of management credibility will reduce their perceptions of disclosure credibility. Given that investors' credibility on firm disclosures is likely to determine their willingness to invest in such company (Triki, Arnold, and Sutton 2015; Triki and Arnold 2016; Triki 2019), we expect the negative effect of CEO narcissism on investors' perception of management credibility (i.e., CEO) and disclosure credibility to reduce investors' willingness to invest.

\footnotetext{
${ }^{6}$ Some studies tested the predictions made in Mercer (2004)'s framework and provided support to those predictions. For example, Mercer (2005) reported that management credibility has a positive and significant impact on investors' willingness to rely on subsequent disclosures. Likewise, Grant et al. (2018) find that CEO credibility mediates the influence of the language (i.e., more or less modest) used by CEOs in corporate communications via different outlets (i.e., conference calls and twitter) on investors' willingness to invest.
} 
Do Investors See the Darkness in Narcissism?

In summary, we expect CEOs' narcissism to have a negative effect on investors' perceptions of management credibility. This lack of credibility in management will make investors less likely to believe in companies' financial disclosures, and as a consequence, less willing to invest. In other words, we predict the effect of CEOs' narcissism on investors' willingness to invest is sequentially mediated by investors' perceptions of management credibility and disclosure credibility. This reasoning motivates the following hypothesis:

H1: CEOs' narcissism has a negative indirect effect on investors' willingness to invest that flows sequentially through investors' perceptions of management credibility and disclosure credibility.

\section{Methods}

\subsection{Design}

We conducted a $2 \times 1$ between-participants experiment to test our hypotheses. ${ }^{7}$ Participants were first presented with a description of a fortune 500 company led by David Egan (CEO) followed by the MD\&A section. Then, participants were randomly assigned to one of two experimental conditions: "low CEO narcissism" and "high CEO narcissism." In both conditions, participants were presented with a news article entitled "CEOs of fortune 500 companies, how narcissistic are they?" that ranked Fortune 500 CEOs based on their degree of narcissism. In the low [high] CEO narcissism condition, David Egan was ranked in the bottom 10\% (rank 470) [top 10\% (rank 30)] of fortune 500 most narcissistic CEOs (see Appendix). ${ }^{8}$ After the news article, participants were presented with additional information about XYZ: analysts forecast and some

\footnotetext{
7 This study received approval from the Institutional Review Board (IRB).

${ }^{8}$ Investors may have access to this types of information from business media. For instance, Jackson (2013), in Forbes, published an article entitled: "The Top 25 Most Narcissistic CEOs In Tech.”.
} 
Do Investors See the Darkness in Narcissism?

financials that showed that the company is in a good financial situation. ${ }^{9}$ Participants were then presented with a series of questions followed by the demographic questions.

\subsection{Measured Variables}

\subsubsection{Management credibility}

Following previous studies, we measure management credibility using a two-item measure: one item to measure competence and one item to measure trust (Koonce and Lipe 2010; Rennekamp 2012; Trinkle et al. 2015). We presented our participants with two items anchored on a 7 point Likert scale ranging from "strongly disagree" to "strongly agree." One questions stated "I believe that David Egan is competent" and the other question stated "I believe that David Egan is trustworthy." The average response on these measures was used as a measure of management credibility.

\subsubsection{Disclosure Credibility}

Consistent with previous literature, we use six items to measure investors' perceptions of disclosure credibility (Chesney and Su 2010; Flanagin and Metzger 2007, 2003, 2000; Triki et al. 2015; Triki and Arnold 2016; Triki 2019). Participants were asked to rate the extent to which the information in the MD\&A section was credible, accurate, trustworthy, unbiased, complete, and reliable. Responses to these six items were also measured by using a seven-point Likert scale ranging from "strongly disagree" to "strongly agree." 10 The average score from these six items was used as a measure of investors' perceptions of disclosure credibility.

\subsubsection{Investors' Willingness to Invest}

\footnotetext{
${ }^{9}$ In our design, XYZ has a good financial performance. We consider that credibility would be especially important for investors who are facing a scenario in which a company provides them with "good news".

${ }^{10}$ We run a principle component analysis on all six items and they all loaded on one factor with an internal reliability of (Cronbach $\alpha=0.90)$.
} 
Do Investors See the Darkness in Narcissism?

In the instructions, participants were told that they have a total of $\$ 50,000$ in savings and that they decided to invest $\$ 10,000$ of their savings in stocks. After reading all of the information related to $X Y Z$, Inc, they were asked how much of the $\$ 10,000$ they wanted to use to invest in XYZ. More precisely, participants were provided with a sliding bar ranging from $\$ 0$ to $\$ 10,000$. In line with prior research (Triki et al. 2015; Triki and Arnold 2016; Triki 2019), we use their answer to this question as a measure of investors' willingness to invest.

\subsection{Participants}

Similar to previous studies, we use Amazon Mechanical Turk (MTurk, hereafter) to reach non-professional investors (Rennekamp 2012; Farkas and Murthy 2014; Triki et al. 2015; Arnold and Triki 2016; Triki 2019). The survey started with three screening questions to make sure that participants have invested at least once and that they had a least one year of investing experience.

${ }^{11}$ Participants that did not meet this screening condition were directed away from the study. ${ }^{12} 222$ participants met the qualifications to participate in the study and were allowed to access the survey. Participants were randomly assigned to the CEO with high narcissism condition or the CEO with low narcissism condition. ${ }^{13}$ The survey included three questions to make sure that participants were paying attention to the experimental materials and to our manipulation. More precisely, the experiment included one attention check question, two comprehension check questions, and a manipulation check question. The attention check question asked about the purpose of the study. Under the question, participants were told that they have to pick a specific option. Those who did

\footnotetext{
11 The questions were adapted from Triki (2019)

${ }^{12}$ We also used filters available in MTurk to improve the quality of our sample. The survey was only accessible to participants located in the US. Additionally, as suggested by previous literature, participants must have completed at least 500 tasks with at least 95\% approval rate (Peer, Vosgerau, and Acquisti 2013; Triki 2019). Individuals in MTurk that did not meet those conditions were not invited to participate.

1396 participants were randomly assigned to the high CEO narcissism condition and 126 participants were randomly assigned to the low CEO narcissism condition.
} 
Do Investors See the Darkness in Narcissism?

not pay attention to the instructions were directed away from the study. ${ }^{14}$ The first [second] comprehension check question asked whether "The $M D \& A$ section included a discussion on XYZ's presence on social media.'[The MD\&A section included a discussion on XYZ's brand recognition]. Participants who failed to answer either of these questions correctly were also directed away from the study. ${ }^{15}$ The manipulation check question asked whether David Egan, based on the news article, was ranked in the top or bottom 10\%. Those who failed either of these questions were directed away from the study. ${ }^{16}$ The final data collection resulted in 153 usable responses.

\section{Results}

Participants had an average of 7.84 years of investing experience and invested an average of 64.71 times in stocks. Approximately, $91.5 \%$ of participants used financial statements to evaluate a company, and $41.8 \%$ had prior business work experience. Participants were predominantly male $(64.1 \%)$ with an average age of 37.73 . The survey included FINRA's five questions measure of financial literacy. Over $80 \%$ of participants answered 4 or more of those questions correctly.

[Insert Table 1 about here]

Before testing the theoretical model, we first investigate the correlation between each of the variables included in the model. As expected, CEOs' Narcissism has a negative correlation with management credibility, disclosure credibility, and willingness to invest. The correlation also indicates that there is a positive association between management credibility and disclosure

\footnotetext{
${ }^{14}$ Ten participants failed the attention check question.

1543 participants failed at least one of the comprehension check questions. Additionally, two participants did not provide an answer and were also excluded from the study.

${ }^{16}$ Ten participants failed the manipulation check question. Also, four participants were removed because they accessed more than one experimental condition.
} 
Do Investors See the Darkness in Narcissism?

credibility, and between disclosure credibility and willingness to invest. Correlations are reported in Table 2.

[Insert Table 2 about here]

We use model 6 in PROCESS (Hayes, 2018), to test the sequential mediation model predicted in our theoretical model. CEO's Narcissism was defined as the predictor, Management Credibility was defined as the first mediating variable, Disclosure Credibility was defined as the second mediating variable, and Investors' Willingness to Invest was defined as the output variable. The sequential mediation path model is tested by using coefficients from three regression models (panel A through $\mathrm{C}$ in Table 3). Results from the mediation analyses are reported in Table 3 (panel D\&E). As expected, the results indicate that CEO's Narcissism has a significant indirect effect on Investors' Willingness to Invest that flows sequentially through Management Credibility and Disclosure Credibility. The bootstrapped confidence intervals for the sequential mediation do not include zero (Boot LLCI =-664.845; Boot ULCI = -150.397). Therefore, our findings indicate that Management Credibility and Disclosure Credibility mediate the effect of CEO's Narcissism on Investors' Willingness to Invest. These results provide support to our hypothesis. The results also show that CEO's Narcissism does not have a direct effect on Investors' Willingness to Invest. Prior research indicates that an indirect effect can be found even if there no direct relationship between the independent variable and the dependent variable e.g., (Zhao, Lynch, and Chen 2010; Rennekamp 2012; Libby, Rennekamp, and Seybert 2015). This finding may indicate that there are other offsetting indirect effects working in the opposite direction of CEO narcissism (e.g., Zhao et al. 2010).

[Insert Table 3 about here] 
Do Investors See the Darkness in Narcissism?

\section{Additional Analyses}

\subsection{Analysis controlling for investment expertise}

In this study, our efforts are concentrated on the judgment and decision making of nonprofessional investors. We focus on non-professional investors because, as a group, they lack the resources that professional investors have at their hand and have less expertise in reading financial statement. Additionally, research on investors' behavior suggest that non-professional investors prefer to use qualitative information (e.g., Arnold, Bedard, Phillips, and Sutton 2010) while professional investors tend to focus more on quantitative information (Hofstedt 1972). As a result, ceteris paribus, non-professional investors are more likely to be impacted by information about CEOs' narcissism.

Although non-professional investors are often treated as a homogeneous group of individuals, its members have different levels of investment experience. Different levels of experience could create sub groups within that class of investors that do not process information similarly (Elliott et al. 2008). Additionally, narcissists often swiftly rise to leadership roles, such as president or Chief Executive Officer (CEO) (Deluga 1997; Maccoby 2000; Rosenthal and Pittinsky 2006; Brunell, Gentry, Campbell, Hoffman, Kuhnert, and Demarree 2008). Investors with experience may build the idea that narcissism is common trait among CEOs and, therefore, may be less likely to be impacted by it. For the reasons stated above, we investigate the impact of investment experience by adding a moderator to the theoretical mode presented in this paper. More precisely, we test whether the effect of CEO's Narcissism on Investors' Willingness to Invest is moderated by the variable Investment Experience. Similar to Elliott et al. (2008), we define this variable as the number of years investing. To test the moderating effect of Investors' Experience, we use Model 85 in PROCESS (Hayes 2018). In this model, we use the same parameters that we 
Do Investors See the Darkness in Narcissism?

had in the main study, but also add years of investment experience as a moderator (See Figure 2). To explore the moderating effect of Investors' Experience at different levels, we use the default condition values in PROCESS: $16^{\text {th }}, 50^{\text {th }}$, and $84^{\text {th }}$ percentiles. The $16^{\text {th }}$ percentile representing individuals with the lowest experience, the $50^{\text {th }}$ percentile representing individuals with a moderate experience, and the $84^{\text {th }}$ percentile representing individuals with the highest experience. Untabulated results, suggest that experience does not moderate the indirect effect of $C E O$ 's Narcissism on Investors' Willingness to Invest.

\subsection{Trust and Competence as proxies of $\mathrm{CEO}$ credibility}

As discussed above, we used investors' trust in the CEO and their perception of his competence as a measure of management credibility. Since management credibility is combination of competence and trust, the indirect effect of narcissism could be mainly driven by competence, trust, or both. To better understand this relationship, we re-run our analyses, with competence and trust as separate variables (see Figure 3). To test our new model, we use model 80 in PROCESS (Hayes 2018). Results from the analyses are reported in Table 4. CEO's Narcissism has an indirect effect on Investors' Willingness to Invest and that effect flows through Trust and Competence.

[Insert Table 4 about here]

\section{Discussion and Conclusion}

Recent evidence suggest that narcissism is on the rise in western society (Konrath et al. 2008) and that many CEOs are inflicted by it (Amernic and Craig 2010). While it may be early to make inferences from a few nascent studies on CEO narcissism, the signs suggest that narcissism may have a negative impact on companies' outcomes. The early signs suggest an association between narcissism and bad corporate practices such as over-investing (Ham et al. 2018), tax sheltering (Olsen and Stekelberg 2016), aggressive estimates (Majo 2016), biased disclosure tones 
Do Investors See the Darkness in Narcissism?

(Marqeuz-Illescas et al. 2019), and unethical conduct (Amernic and Craig 2010; Rijsenbilt and Commandeur 2013). This literature focuses mainly on managers and does not investigate the potential effect of CEO narcissism on investors' judgment and decision making. This study identifies this gap and investigates whether CEO narcissism influences investors' willingness to invest. We specifically posit that investors will perceive more narcissistic CEOs to be less credible, and thus, they will perceive financial disclosures coming from these CEOs to be less credible too. Ultimately, we claim this CEO narcissism-driven lack of credibility reduces investor's willing to invest. Our findings indicate that in fact, investors perceive more narcissistic CEOs to be less credible, and thus, they are less likely to believe the financial disclosures coming from companies led by these types of CEOs. As a consequence of this lack of credibility, we find that CEOs' narcissism has a negative effect on investors' willingness to invest.

By investigating the effect of narcissism on investors' judgment and decision making, we fill a gap in the literature and make several contributions to research and practice. Prior research investigates the degree to which CEO narcissism influences different kinds of firm-level outcomes. However, whether non-professional investors are aware of these negative consequences of CEO narcissism stated by prior research is somewhat questionable. Most likely, the effect of CEO narcissism on firm outcomes will not influence investors' decisions until the consequences of CEOs' decisions are observable. In other words, these studies suggest that CEOs' narcissism might influence investors' willingness to invest through other channels, such as financial performance. We show that the effect of CEOs' narcissism on investors' behavior might be more immediate and is associated with a reputational effect. In other words, we explore a consequence of CEOs' narcissism that might not depend on the effect of CEOs' narcissism on firm outcomes, but on the "narcissistic" reputation of CEOs. This expands prior literature exploring the effect of CEOs' 
Do Investors See the Darkness in Narcissism?

personality traits on firm outcomes. Prior research on this topic focuses on how CEOs' narcissism influences firm outcomes. We show that the effect of CEOs' narcissism may act though different channels. Concretely, we provide evidence suggesting that non-professional investors' awareness of CEOs' personality might exert an effect on their investing decisions. Therefore, our results indicate that companies might want to monitor the public image of CEOs (press releases, social networks) so it does not reduce investors' willingness to invest.

Additionally, our findings suggest that the effect of CEOs' narcissism on investors' willingness to invest does not depend on investment experience. Non-professional investors with more experience reacted similarly to CEOs' narcissism as investors with lower experience. These results suggest that, within our sample of non-professional investors, investors' view of CEO narcissism does not change as they accumulate more investment experience. Since professional investors may behave differently compared to non-professional investors, we cannot generalize these findings to professional investors.

Our study creates new research questions for future studies to address. We only focused on one of the three dark traits that managers can have. While research suggests that there is an overlap between those three traits, they are independent constructs (Jones and Paulhus 2014). In this manuscript, we only focus on narcissism. We believe that future studies should investigate the effect of each of the remaining components of the dark triad separately and jointly. In the same vein, our findings indicate that when facing the decision to choose among two companies, nonprofessional investors may decide to invest in the company that is led by a less narcissistic CEO. Future research might try explore whether stock abnormal returns following corporate disclosures include a discount or premium related with CEO narcissism. Finally, we explore a case in which a company is reporting a favorable financial performance. In other words, a case in which a firm 
Do Investors See the Darkness in Narcissism?

is reporting "good news". It may be the case that the causality chain proposed in this study does not hold if companies are reporting "bad news" because investors might find less reasonable to question the credibility of "negative" disclosures. This could be a promising empirical question to test in future research. 
Do Investors See the Darkness in Narcissism?

\section{REFERENCES}

Amernic, J., and Craig, R. 2010. Accounting as a Facilitator of Extreme Narcissism. Journal of Business Ethics 96(1): 79-93.

Araujo-Cabrera, Y., Suarez-Acosta, M. A., and Aguiar-Quintana, T. 2017. Exploring the influence of CEO extraversion and openness to experience on firm performance: The mediating role of top management team behavioral integration. Journal of Leadership \& Organizational Studies 24(2): 201-215.

Arnold, V., Bedard, J. C., Phillips, J. R, and Sutton, S. G. 2010. Where do investors prefer to find nonfinancial information? Journal of Accountancy. August 23. Available online at http://www.journalofaccountancy.com/Web/20102682

Azouzi, M. A., and Jarboui, A. 2017. CEO emotional intelligence and firm dividend policy: decision tree analysis. International Journal of Monetary Economics and Finance 10(1): 2446.

Back, M. D., Schmukle, S. C., \& Egloff, B. 2010. Why are narcissists so charming at first sight? Decoding the narcissism-popularity link at zero acquaintance. Journal of personality and social psychology, 98(1): 132-145.

Barton, J., and M. Mercer. 2005. To blame or not to blame: Analysts' reactions to external explanations for poor financial performance. Journal of Accounting and Economics 39 (3): 509-533.

Behesti, N. 2018. Can A Narcissistic CEO Destroy Their Company? Forbes. Retrieved from: https://www.cnn.com/2018/11/05/success/narcissist-ceo/index.html

Blanding, M. 2018. So sue me: Why narcissistic CEOs can get their firms into legal trouble. BerkeleyHass (August 29). Retrieved from: http://newsroom.haas.berkeley.edu/whynarcissistic-ceos-make-their-companies-vulnerable-lawsuits/

Becker, J., Medjedovic, J., and Merkle, C. 2019. The Effect of CEO Extraversion on Analyst Forecasts: Stereotypes and Similarity Bias. Financial Review 54(1): 133-164.

Brunell, A. B., Gentry, W. A., Campbell, W.K., Hoffman, B. J., Kuhnert, K. W., and DeMarree, K. G. 2008. Leader Emergence: The Case of the Narcissistic Leader. Personality and Social Psychology Bulletin 34(12): 1663-1676.

Boddy, C. R. 2017. Psychopathic leadership a case study of a corporate psychopath CEO. Journal of Business Ethics 145(1): 141-156.

Campbell, W. K., G. D. Reeder, C. Sedikides, and A. J. Elliot. 2000. Narcissism and comparative selfenhancement strategies. Journal of Research in Personality: 329-347. 
Do Investors See the Darkness in Narcissism?

Campbell, W. K. 2001. Is narcissism really so bad? Psychological Inquiry 12(4): 214-216.

Chatterjee, A., and Hambrick, D. 2007. It's All about Me: Narcissistic Chief Executive Officers and Their Effects on Company Strategy and Performance. Administrative Science Quarterly 52(3): 351-386.

Chatterjee, A., and Hambrick, D. 2011. Executive Personality, Capability Cues, and Risk Taking. Administrative Science Quarterly 56(2): 202-237.

Chesney, T., and D. Su. 2010. The impact of anonymity on weblog credibility. International Journal of Human-Computer Studies 68 (10): 710-718.

Cianci, A. M., and S. E. Kaplan. 2010. The effect of CEO reputation and explanations for poor performance on investors' judgments about the company's future performance and management. Accounting, Organizations, and Society 35(4):478-495.

Deluga, R. J. 1997. Relationship among American presidential charismatic leadership, narcissism, and rated performance. The Leadership Quarterly 8(1): 49-65.

Elliott, W., F. Hodge, and K. E. Jackson. 2008. The Association between Nonprofessional Investors' Information Choices and Their Portfolio Returns: The Importance of Investing Experience. Contemporary Accounting Research 25(2):473-498

Engelen, A., Neumann, C., and Schmidt, S. (2016). Should entrepreneurially oriented firms have narcissistic CEOs? Journal of Management 42(3): 698-721.

Flanagin, A., and M. Metzger. 2000. Perceptions of internet information credibility. Journalism \& Mass Communication Quarterly 77 (3): 515-540.

Farkas, M., and U. Murthy. 2014. Nonprofessional investors' perceptions of the incremental value of continuous auditing and continuous controls monitoring: An experimental investigation. International Journal of Accounting Information Systems 15 (2): 102-121.

Flanagin, A., and M. Metzger. 2003. The perceived credibility of personal web page information as influenced by the sex of the source. Computers in Human Behavior 19 (6): 683-701.

Flanagin, A., and M. Metzger. 2007. The role of site features, user attributes, and information verification behaviors on the perceived credibility of web-based information. New Media \& Society 9 (2): 319-342.

Furtner, M. R., Rauthmann, J. F., \& Sachse, P. (2011). The self-loving self-leader: an examination of the relationship between self-leadership and the dark triad. Social Behavior and Personality: an international journal, 39(3): 369-379.

Galasso, A., \& Simcoe, T. S. (2011). CEO overconfidence and innovation. Management Science, 57(8): 1469-1484. 
Do Investors See the Darkness in Narcissism?

Gerstner, W. C., König, A., Enders, A., \& Hambrick, D. C. 2013. CEO narcissism, audience engagement, and organizational adoption of technological discontinuities. Administrative Science Quarterly 58(2): 257-291.

Grant, S. M., Hodge, F. D, and Sinha, R. K. 2018. How Disclosure Medium Affects Investor Reactions to CEO Bragging, Modesty, and Humblebragging. Accounting, Organizations and Society 68: 118-34.

Ham, C., Lang, M., Seybert, N. and Wang, S. 2017. CFO narcissism and financial reporting quality. Journal of Accounting Research 55(5): 1089-1135.

Ham, C., Seybert, N., and Wang, S. 2018. Narcissism is a bad sign: CEO signature size, investment, and performance. Review of Accounting Studies 23(1): 234-264.

Ham, C., Lang, M., Seybert, N., and Wang, S. 2017. CFO narcissism and financial reporting quality. Journal of Accounting Research 55(5): 1089-1135.

Harrison, J., Thurgood, G. R., Boivie, S., and Pfarrer, M. 2.019. Perception Is Reality: How CEOs' Observed Personality Influences Market Perceptions of Firm Risk and Shareholder Returns. Academy of Management Journal, (ja).

Hayes, A. 2018. Introduction to Mediation, Moderation, and Conditional Process Analysis (2 $2^{\text {nd }}$ ed.). New York: Guilford Press.

Hofstedt, T. R. 1972. Some behavioral parameters of financial analysis. The Accounting Review 47 (4): 679-692.

Hoffman, B. J., Strang, S. E., Kuhnert, K. W., Campbell, W.K., Kennedy, C. L., and LoPilato, A. C. 2013. Leader Narcissism and Ethical Context: Effects on Ethical Leadership and Leader Effectiveness. Journal of Leadership \& Organizational Studies 20(1): 25-37.

Hovland, C., I. Janis, and H. Kelley. 1953. Communication and Persuasion. New Haven, CT: Yale University Press.

Hsieh, T. S., Wang, Z., and Demirkan, S. 2018. Overconfidence and tax avoidance: The role of CEO and CFO interaction. Journal of Accounting and Public Policy 37(3): 241-253.

INSEAD Knowledge. 2014. Narcissistic CEOs are more destructive than you think. Forbes (June 3). Retrieved from: https://www.forbes.com/sites/insead/2014/06/03/narcissistic-ceosare-more-destructive-than-you-think/\#a422a0d7ff85

Jackson, E. 2012. Why Narcissistic CEOs kill their companies. Forbes (Jan 11). Retrieved from: https://www.forbes.com/sites/ericjackson/2012/01/11/why-narcissistic-ceos-kill-theircompanies/\#45a51ab9304b 
Do Investors See the Darkness in Narcissism?

Jackson, E. 2013. The Top 25 Most Narcissistic CEOs in Tech. Forbes (September 16). Retrieved from https://www.forbes.com/sites/ericjackson/2013/09/16/the-top-25-mostnarcissistic-ceos-in-tech/\#3b53bf9868a7

Johnson, E. N., Kuhn, J. R., Apostolou, B. A., \& Hassell, J. M. 2013. Auditor perceptions of client narcissism as a fraud attitude risk factor. AUDITING: A Journal of Practice \& Theory 32(1): 203-219.

Jones, D. N., and Paulhus, D. L. 2014. Introducing the Short Dark Triad (SD3): A Brief Measure of Dark Personality Traits. Assessment 21(1): 28-41.

Koonce, L., and Lipe, M. 2010. Earnings Trend and Performance Relative to Benchmarks: How Consistency Influences Their Joint Use. Journal of Accounting Research 48(4): 859.

Krische, S. D., Sanders, P. R., and Smith, S. D. 2014. Management credibility and investment risk: An experimental investigation of lease accounting alternatives. Behavioral Research in Accounting 26(1): 109-130.

Kuang, Y. F., Mohan, A., and Qin, B. 2015. CEO overconfidence and cost stickiness. Management Control \& Accounting (2): 26-32.

Libby, R., Rennekamp, K. M., \& Seybert, N. 2015. Regulation and the interdependent roles of managers, auditors, and directors in earnings management and accounting choice. Accounting, Organizations and Society (47): 25-42.

Maccoby, M. 2000. Narcissistic leaders: The incredible pros, the inevitable cons. Harvard Business Review 78(1): 69-77.

Majors, T. M. 2016. The interaction of communicating measurement uncertainty and the dark triad on managers' reporting decisions. The Accounting Review 91(3): 973-992.

Malkin, M. L., Zeigler-Hill, V., Barry, C. T., \& Southard, A. C. (2013). The view from the looking glass: How are narcissistic individuals perceived by others?. Journal of personality, 81(1): 1-15.

Marquez-Illescas, G., Zebedee, A.A. and Zhou, L. 2018.Hear Me Write: Does CEO Narcissism Affect Disclosure? Journal of Business Ethics. https://doi.org/10.1007/s 10551-018-3796-3

McGregor, J. 2013. The least narcissistic American CEOs. The Washington Post. Retrieved from: https://www.washingtonpost.com/news/on-leadership/wp/2013/12/27/the-least$\underline{\text { narcissistic-american-ceos/ }}$

Mercer, M. 2004. How do investors assess the credibility of management disclosures? Accounting Horizons 18 (3): 185-196. 
Do Investors See the Darkness in Narcissism?

Morf, C. C., and Rhodewalt, F. 2001. Expanding the dynamic self-regulatory processing model of narcissism: Research directions for the future. Psychological Inquiry 12(4): 243-251.

Ng, J., Tuna, I., and Verdi, R. 2013. Management forecast credibility and underreaction to news. Review of Accounting Studies, 18(4), 956-986.

Nordqvist, C. 2018. Narcissistic CEOs tend to have larger legal bills. Market Business News $(M B N)$. Retrieved from: https://marketbusinessnews.com/narcissistic-ceos/185931/

O'Reilly III, C. A., Doerr, B., and Chatman, J. A. 2018. "See you in court": How CEO narcissism increases firms' vulnerability to lawsuits. The Leadership Quarterly 29(3): 365378

Olsen, K. J., Dworkis, K. K., and Young, S. M. 2014. CEO narcissism and accounting: A picture of profits. Journal of Management Accounting Research 26(2): 243-267.

Olsen, K. J., and Stekelberg, J. 2016. CEO narcissism and corporate tax sheltering. The Journal of the American Taxation Association 38(1): 1-22.

Ou, A. Y., Waldman, D. A., and Peterson, S. J. 2018. Do humble CEOs matter? An examination of CEO humility and firm outcomes. Journal of Management 44(3): 1147-1173.

Park, J. H., Kim, C., Chang, Y. K., Lee, D. H., and Sung, Y. D. 2018. CEO hubris and firm performance: Exploring the moderating roles of CEO power and board vigilance. Journal of Business Ethics 147(4): 919-933.

Patel, D. 2017. 7 Personality traits Every CEO Should Have. Forbes (Jun 15). Retrieved from: https://www.forbes.com/sites/deeppatel/2017/06/15/7-personality-traits-every-ceo-shouldhave/\#6fc2b0261f02

Peer, E., Vosgerau, J., and Acquisti, A., 2013. Reputation as a sufficient condition for data quality on amazon mechanical turk. Behavioral Research Methods 46 (4), 1023-1031.

Petrenko, O. V., Aime, F., Ridge, J., and Hill, A. 2016. Corporate social responsibility or CEO narcissism? CSR motivations and organizational performance. Strategic Management Journal 37(2): 262-279.

Pornpitakpan, C. 2004. The persuasiveness of source credibility: A critical review of five decades' evidence. Journal of Applied Social Psychology 34 (2): 243-281.

Rennekamp, K. 2012. Processing fluency and investors? Reactions to disclosure readability. Journal of Accounting Research 50 (5): 1319-1354.

Resick, C. J., D. S. Whitman, S. M. Weingarden, and N. J. Hiller. 2009. The bright side and the dark side of CEO personality: Examining core self-evaluations, narcissism, transformational leadership, and strategic influence. Journal of Applied Psychology: 1365-1381. 
Do Investors See the Darkness in Narcissism?

Rauthmann, J. F., and Kolar, G. P. 2012. How "dark" are the dark triad traits? examining the perceived darkness of narcissism, Machiavellianism, and psychopathy. Personality and Individual Differences 53(7): 884-889.

Rijsenbilt, A. and Commandeur, H.2013. Narcissus Enters the Courtroom: CEO Narcissism and Fraud. Journal of Business Ethics 117(2): 413-429.

Rosenthal, S. A., and Pittinsky, T. L. 2006. Narcissistic leadership. The Leadership Quarterly 17 (6): 617-633.

Sahadi, J. 2018. How narcissistic CEOs put companies at risk. CNN Business. Retrieved from: https://www.cnn.com/2018/11/05/success/narcissist-ceo/index.html

Smith, M. B., Hill, A. D., Wallace, J. C., Recendes, T., and Judge, T. A. 2018. Upsides to dark and downsides to bright personality: A multidomain review and future research agenda. Journal of Management 44(1): 191-217.

Tang, Y., Qian, C., Chen, G., and Shen, R. 2015. How CEO hubris affects corporate social (ir) responsibility. Strategic Management Journal 36(9): 1338-1357.

Trinkle, B. S., Crossler, R. E., and Bélanger, F. 2015. Voluntary disclosures via social media and the role of comments. Journal of Information Systems 29(3): 101-121.

Triki, A., V. Arnold., and S. G. Sutton. 2015. Too Good to be True! The Bifurcated Effect of Strong Tone in Management Disclosures on Investors' Decisions. Advances in Accounting Behavioral Research: 1-31.

Triki, A., and V. Arnold. 2016. Getting Caught Sugar Coating: The Behavioral Implications of Using a Decision Aid That Detects Linguistic Manipulations in Financial Disclosures. Journal of Emerging Technologies in Accounting 13(2): 169-184.

Triki, A. 2019. Examining the Effect of Deception Detection Decision Aids on Investors' Perceptions of Disclosure Credibility and Willingness to Invest. International Journal of Accounting Information Systems. https://doi.org/10.1016/j.accinf.2019.03.003

Twenge, J. M., and Campbell, W. K. 2003. 'Isn't it fun to get the respect that we're going to deserve?" Narcissism, social rejection, and aggression. Personality and Social Psychology Bulletin 29(2): 261-272.

Wallace, H. M., and R. F. Baumeister. 2002. The performance of narcissists rises and falls with perceived opportunity for glory. Journal of Personality and Social Psychology: 819-834

Wood, M. 2018. Are narcissistic CEOs bad for business? Marketplace. Retrieved from: https://www.marketplace.org/2018/10/15/are-narcissistic-ceos-bad-business/ 
Do Investors See the Darkness in Narcissism?

Young, S. M., Du, F., Dworkis, K. K., and Olsen, K. J. 2016. It's all about all of us: The rise of narcissism and its implications for management control system research. Journal of Management Accounting Research 28(1): 39-55.

Zhang, H., Ou, A. Y., Tsui, A. S., and Wang, H. 2017. CEO humility, narcissism and firm innovation: A paradox perspective on CEO traits. The Leadership Quarterly 28(5): 585-604.

Zhao, X., Lynch Jr, J. G., \& Chen, Q. (2010). Reconsidering Baron and Kenny: Myths and truths about mediation analysis. Journal of consumer research 37(2): 197-206. 
Do Investors See the Darkness in Narcissism?

Figure 1 Theoretical Model

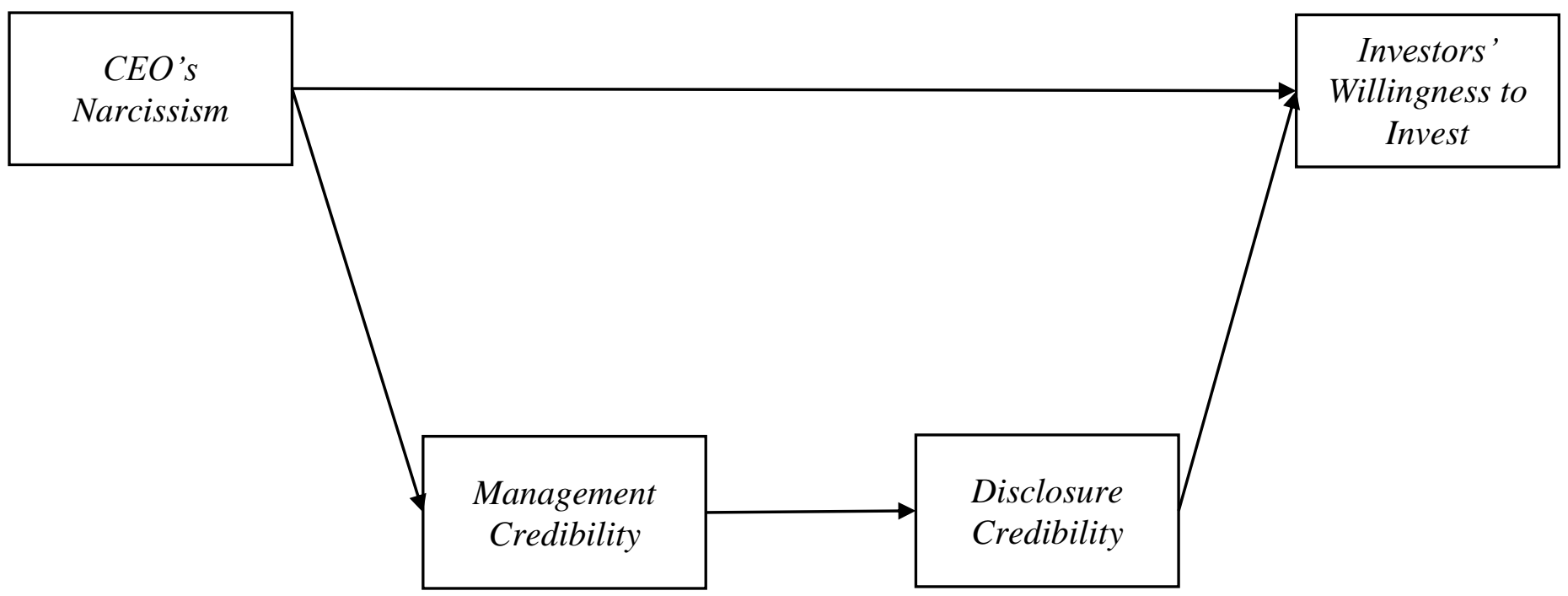


Do Investors See the Darkness in Narcissism?

Figure 2 Supplemental Analyses

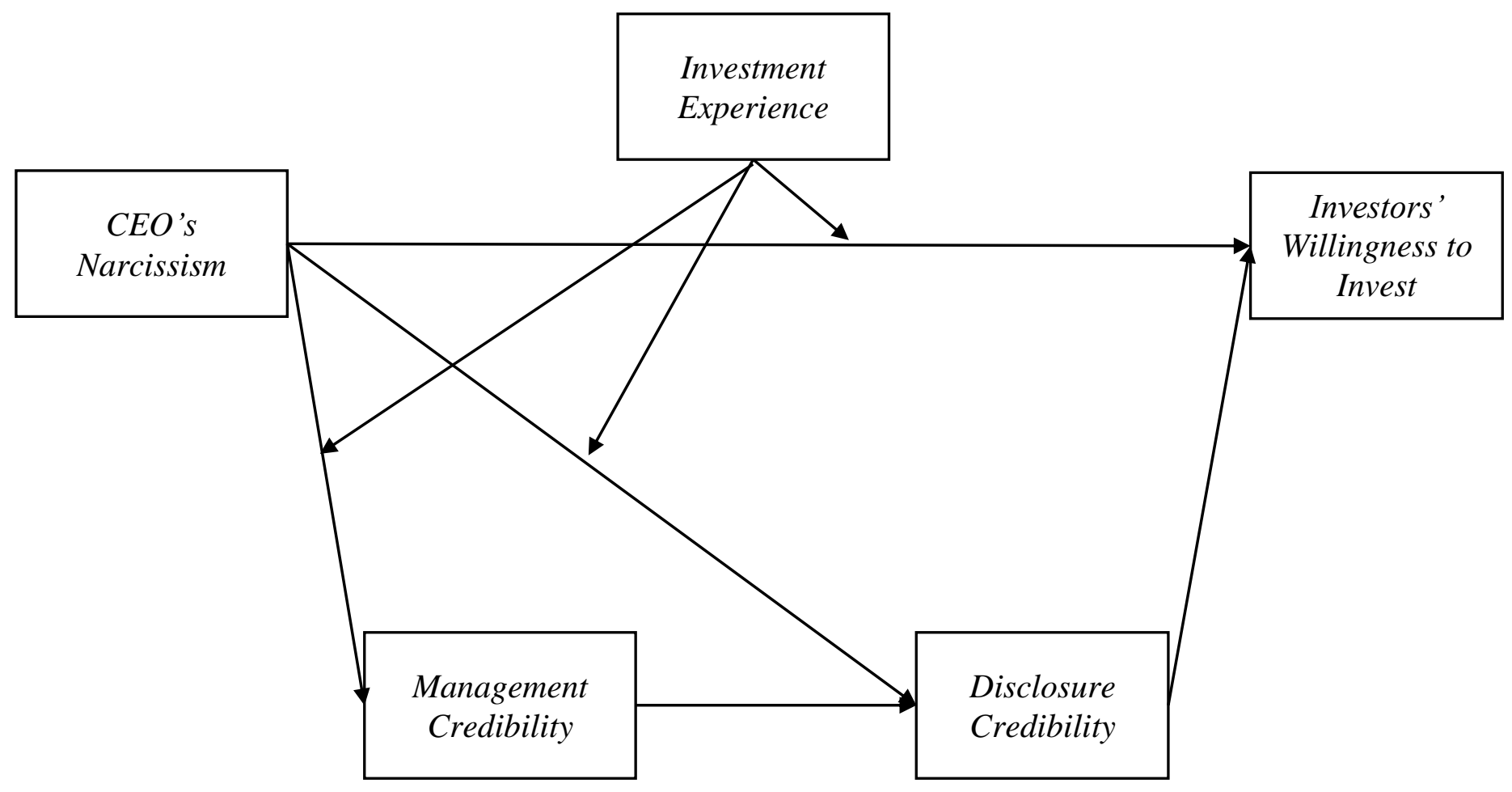


Do Investors See the Darkness in Narcissism?

Figure 3 Supplemental Analyses

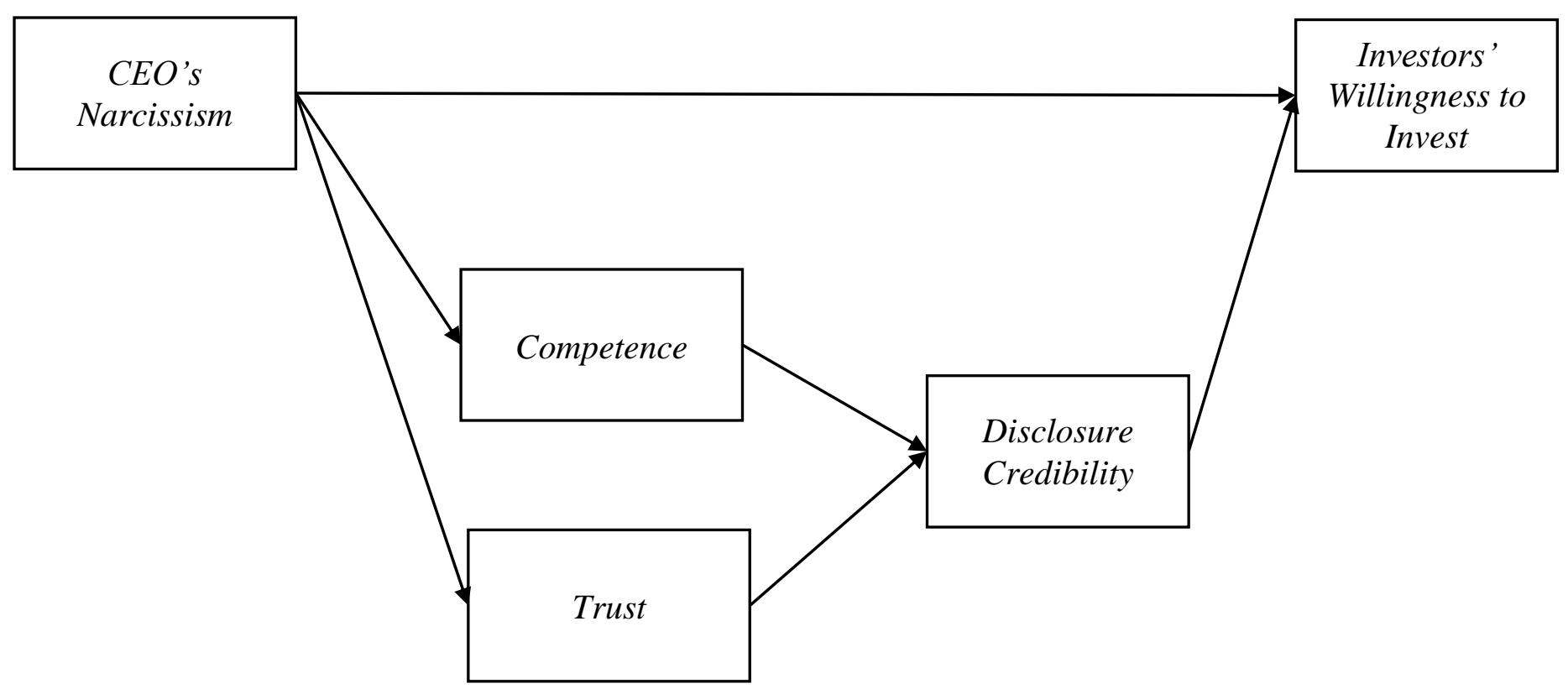


Do Investors See the Darkness in Narcissism?

TABLE 1

Demographic Information

\begin{tabular}{|c|c|c|}
\hline & $\underline{\text { Mean }}$ & $\underline{\text { Standard }}$ \\
\hline Average number of years of investing experience & 7.84 & 7.335 \\
\hline $\begin{array}{l}\text { Average number of times making purchases of common } \\
\text { stock }\end{array}$ & 64.71 & 245.305 \\
\hline \multirow[t]{2}{*}{ Age } & 37.73 & 10.366 \\
\hline & $\underline{\text { Number }}$ & Percent \\
\hline \multicolumn{3}{|l|}{ Gender } \\
\hline Male & 98 & 64.1 \\
\hline Female & 53 & 34.6 \\
\hline Prefer not to Answer & 2 & 1.3 \\
\hline \multicolumn{3}{|l|}{ Ethnicity } \\
\hline Asian & 14 & 9.2 \\
\hline African American & 12 & 7.8 \\
\hline Hispanic & 7 & 4.6 \\
\hline Caucasian & 116 & 75.8 \\
\hline Others & 3 & 2.0 \\
\hline Prefer not to Answer & 1 & 0.7 \\
\hline \multicolumn{3}{|l|}{ Education } \\
\hline High School Graduate & 13 & 8.5 \\
\hline Some College & 22 & 14.4 \\
\hline 2-year college degree & 14 & 9.2 \\
\hline 4 year degree & 80 & 52.3 \\
\hline Professional degree & 21 & 13.7 \\
\hline Doctorate & 3 & 2.0 \\
\hline \multicolumn{3}{|l|}{$\begin{array}{l}\text { Used Financial Statements to Evaluate Company } \\
\text { Performance }\end{array}$} \\
\hline Yes & 140 & 91.5 \\
\hline No & 13 & 8.5 \\
\hline \multicolumn{3}{|l|}{$\begin{array}{l}\text { Prior Business Work Experience (Average is } 12.47 \\
\text { years) }\end{array}$} \\
\hline Yes & 64 & 41.8 \\
\hline No & 89 & 58.2 \\
\hline \multicolumn{3}{|l|}{$\begin{array}{l}\text { Prior Work Experience in financial analysis (Average is } \\
4.19 \text { years) }\end{array}$} \\
\hline Yes & 21 & 13.7 \\
\hline No & 132 & 86.3 \\
\hline \multicolumn{3}{|l|}{ Plan to Invest in Common Stock in Future } \\
\hline Yes & 150 & 98.0 \\
\hline No & 3 & 2.0 \\
\hline
\end{tabular}


Do Investors See the Darkness in Narcissism?

\begin{tabular}{|l|r|r|}
\hline Participants who had five correct answers & 76 & 49.7 \\
\hline Participants who had four correct answers & 51 & 33.3 \\
\hline Participants who had three correct answers & 19 & 12.4 \\
\hline Participants who had two correct answers & 4 & 2.6 \\
\hline Participants who had one correct answers & 2 & 1.3 \\
\hline Participants who had no correct answers & 1 & 0.7 \\
\hline
\end{tabular}


Do Investors See the Darkness in Narcissism?

TABLE 2

Correlation Matrix

\begin{tabular}{|l|c|c|c|c|}
\hline \multicolumn{1}{|c|}{ Correlations } \\
\hline & $\begin{array}{c}\text { CEO's } \\
\text { Narcissism }\end{array}$ & $\begin{array}{c}\text { Management } \\
\text { Credibility }\end{array}$ & $\begin{array}{c}\text { Disclosure } \\
\text { Credibility }\end{array}$ & $\begin{array}{c}\text { Investors' } \\
\text { Willingness to } \\
\text { Invest }\end{array}$ \\
\hline CEO's Narcissism & 1 & $-.341^{* *}$ & -.013 & $-.175^{*}$ \\
\hline Management credibility & $-.341^{* *}$ & 1 & $.586^{* *}$ & $.393^{* *}$ \\
\hline Disclosure Credibility & -.013 & $.586^{* *}$ & 1 & $.396^{* *}$ \\
\hline $\begin{array}{l}\text { Investors' Willingness to } \\
\text { Invest }\end{array}$ & $-.175^{*}$ & $.393^{* *}$ & $.396^{* *}$ & 1 \\
\hline
\end{tabular}

**. Correlation is significant at the 0.01 level (2-tailed).

*. Correlation is significant at the 0.05 level (2-tailed). 
Do Investors See the Darkness in Narcissism?

TABLE 3

The effect of CEO's Narcissism on Investors' Willingness to Invest

Panel A: The Effect of CEO's Narcissism on Management's Credibility

\begin{tabular}{|l|c|c|c|c|c|c|}
\hline & Coefficient & SE & $\mathrm{t}$ & $\begin{array}{c}\text { Sig. } \\
\text { (One- } \\
\text { tailed })\end{array}$ & LLCI & ULCI \\
\hline (Constant) & 6.037 & 0.093 & 65.078 & $<\mathbf{0 . 0 0 1}$ & 5.883 & 6.190 \\
\hline CEO's Narcissism & -0.607 & 0.136 & -4.458 & $<\mathbf{0 . 0 0 1}$ & -0.832 & -0.382 \\
\hline
\end{tabular}

Panel B: The Effect of CEO's Narcissism and Management Credibility on Disclosure Credibility

\begin{tabular}{|l|c|c|c|c|c|c|}
\hline & Coefficient & SE & $\mathrm{t}$ & $\begin{array}{c}\text { Sig. } \\
\text { (One- } \\
\text { tailed) }\end{array}$ & LLCI & ULCI \\
\hline (Constant) & 1.482 & 0.418 & 3.542 & $<\mathbf{0 . 0 0 1}$ & 0.790 & 2.175 \\
\hline $\begin{array}{l}\text { Management } \\
\text { Credibility }\end{array}$ & 0.657 & 0.068 & 9.639 & $<\mathbf{0 . 0 0 1}$ & 0.544 & 0.769 \\
\hline CEO's Narcissism & 0.376 & 0.121 & 3.101 & $\mathbf{0 . 0 0 1}$ & 0.175 & 0.577 \\
\hline
\end{tabular}

Panel C: The effect of Management Credibility, Disclosure credibility, and CEO's Narcissism on Investors' Willingness to Invest

\begin{tabular}{|l|c|c|c|c|c|c|}
\hline & Coefficient & SE & $\mathrm{t}$ & $\begin{array}{c}\text { Sig. } \\
\text { (One- } \\
\text { tailed) }\end{array}$ & LLCI & ULCI \\
\hline $\begin{array}{l}\text { (Constant) } \\
\text { Credibility }\end{array}$ & -3020.012 & 1567.223 & -1.927 & $\mathbf{0 . 0 2 8}$ & -5613.992 & -426.032 \\
\hline Disclosure Credibility & 892.840 & 311.869 & 1.933 & $\mathbf{0 . 0 2 8}$ & 86.651 & 1119.028 \\
\hline CEO's Narcissism & -599.439 & 449.978 & -1.332 & $\mathbf{0 . 0 9 2}$ & -1344.217 & 145.339 \\
\hline
\end{tabular}


Do Investors See the Darkness in Narcissism?

TABLE 3 (Cont.)

Panel D: The Direct Effect of CEO's Narcissism on Investors' Willingness to Invest

\begin{tabular}{|c|c|c|c|c|c|}
\hline Effect & SE & $\mathrm{t}$ & $\begin{array}{c}\text { Sig. } \\
(\text { One- } \\
\text { tailed })\end{array}$ & LLCI & ULCI \\
\hline-599.439 & 449.978 & -1.332 & 0.092 & -1344.217 & 145.339 \\
\hline
\end{tabular}

Panel E: The Indirect Effects of CEO's Narcissism and Investors' Willingness to Invest

\begin{tabular}{|l|c|c|c|c|}
\hline \multicolumn{1}{|c|}{ Mediator } & Effect & Boot SE & Boot LLCI & $\begin{array}{c}\text { Boot } \\
\text { ULCI }\end{array}$ \\
\hline Management Credibility & -365.928 & 214.809 & $\mathbf{- 8 1 7 . 4 9 0}$ & $\mathbf{- 8 9 . 6 3 4}$ \\
\hline Disclosure Credibility & 336.174 & 163.760 & $\mathbf{1 2 2 . 0 7 0}$ & $\mathbf{6 7 7 . 1 0 1}$ \\
\hline $\begin{array}{l}\text { Management Credibility and Disclosure } \\
\text { Credibility }\end{array}$ & -356.372 & 154.269 & $\mathbf{- 6 6 4 . 8 4 5}$ & $\mathbf{- 1 5 0 . 3 9 7}$ \\
\hline
\end{tabular}

P-values in bold are significant at the 0.05 level $(\mathrm{p}=\mathrm{b} 0.05)$.

Bootstrapped confidence intervals in bold indicate the absence of zero within the bootstrapped confidence intervals at a confidence level of $90 \%$. 
Do Investors See the Darkness in Narcissism?

TABLE 4

The effect of CEO's Narcissism on Investors' Willingness to Invest

Panel A: The Effect of CEO's Narcissism on Competence

\begin{tabular}{|l|c|c|c|c|c|c|}
\hline & Coefficient & SE & $\mathrm{t}$ & $\begin{array}{c}\text { Sig. } \\
\text { (One- } \\
\text { tailed })\end{array}$ & LLCI & ULCI \\
\hline (Constant) & 6.134 & 0.083 & 73.675 & $<\mathbf{0 . 0 0 1}$ & 5.996 & 6.272 \\
\hline CEO's Narcissism & -0.233 & 0.122 & -1.904 & $\mathbf{0 . 0 2 9}$ & -0.435 & -0.031 \\
\hline
\end{tabular}

Panel B: The Effect of CEO's Narcissism on Trust

\begin{tabular}{|l|c|c|c|c|c|c|}
\hline & Coefficient & SE & $\mathrm{t}$ & $\begin{array}{c}\text { Sig. } \\
\text { (One- } \\
\text { tailed) }\end{array}$ & LLCI & ULCI \\
\hline (Constant) & 5.939 & 0.120 & 49.594 & $<\mathbf{0 . 0 0 1}$ & 5.741 & 6.137 \\
\hline CEO's Narcissism & -0.981 & 0.176 & -5.582 & $<\mathbf{0 . 0 0 1}$ & -1.272 & -0.690 \\
\hline
\end{tabular}

Panel C: The Effect of CEO's Narcissism, Competence, and Trust on Disclosure Credibility

\begin{tabular}{|l|c|c|c|c|c|c|}
\hline & Coefficient & SE & $\mathrm{t}$ & $\begin{array}{c}\text { Sig. } \\
\text { (One- } \\
\text { tailed) }\end{array}$ & LLCI & ULCI \\
\hline (Constant) & 9.511 & 2.839 & 3.350 & $\mathbf{0 . 0 0 1}$ & 4.812 & 14.210 \\
\hline CEO's Narcissism & 2.363 & 0.764 & 3.092 & $\mathbf{0 . 0 0 1}$ & 1.098 & 3.629 \\
\hline Competence & 1.700 & 0.607 & 2.802 & $\mathbf{0 . 0 0 3}$ & 0.696 & 2.705 \\
\hline Trust & 2.143 & 0.422 & 5.079 & $<\mathbf{0 . 0 0 1}$ & 1.445 & 2.842 \\
\hline
\end{tabular}

Panel D: The effect of Competence, Trust, Disclosure credibility, and CEO's Narcissism on Investors' Willingness to Invest

\begin{tabular}{|l|c|c|c|c|c|c|}
\hline & Coefficient & SE & $\mathrm{t}$ & $\begin{array}{c}\text { Sig. } \\
\text { (One- } \\
\text { tailed) }\end{array}$ & LLCI & ULCI \\
\hline (Constant) & -2646.584 & 1765.679 & -1.499 & 0.068 & -5569.161 & 275.994 \\
\hline CEO's Narcissism & -533.703 & 472.912 & -1.129 & 0.130 & -1316.473 & 249.068 \\
\hline Competence & 144.124 & 373.487 & 0.386 & 0.350 & -474.077 & 762.326 \\
\hline Trust & 405.839 & 274.125 & 1.481 & 0.070 & -47.896 & 859.574 \\
\hline Disclosure Credibility & 148.165 & 49.132 & 3.016 & $\mathbf{0 . 0 0 2}$ & 66.841 & 229.489 \\
\hline
\end{tabular}


Do Investors See the Darkness in Narcissism?

TABLE 4 (Cont.)

Panel E: The Direct Effect of CEO's Narcissism on Investors' Willingness to Invest

\begin{tabular}{|c|c|c|c|c|c|}
\hline Effect & SE & $\mathrm{t}$ & $\begin{array}{c}\text { Sig. } \\
(\text { One- } \\
\text { tailed })\end{array}$ & LLCI & ULCI \\
\hline-533.703 & 472.912 & -1.129 & 0.130 & -1316.473 & 249.068 \\
\hline
\end{tabular}

Panel F: The Indirect Effects of CEO's Narcissism and Investors' Willingness to Invest

\begin{tabular}{|l|c|c|c|c|}
\hline \multicolumn{1}{|c|}{ Mediator } & Effect & Boot SE & Boot LLCI & $\begin{array}{c}\text { Boot } \\
\text { ULCI }\end{array}$ \\
\hline Competence & -33.543 & 109.196 & -229.543 & 125.547 \\
\hline Trust & -398.241 & 262.289 & $\mathbf{- 8 5 8 . 6 7 3}$ & $\mathbf{- 6 . 6 0 9}$ \\
\hline Disclosure Credibility & 350.178 & 175.082 & $\mathbf{8 5 . 2 5 3}$ & $\mathbf{6 5 1 . 8 7 3}$ \\
\hline Competence and Disclosure Credibility & -58.637 & 44.883 & $\mathbf{- 1 4 0 . 5 4 2}$ & $\mathbf{- 0 . 8 4 5}$ \\
\hline Trust and Disclosure Credibility & -311.620 & 133.867 & $\mathbf{- 5 4 2 . 3 8 1}$ & $\mathbf{- 1 0 5 . 4 9 8}$ \\
\hline
\end{tabular}

P-values in bold are significant at the 0.05 level $(\mathrm{p}=\mathrm{b} 0.05)$.

Bootstrapped confidence intervals in bold indicate the absence of zero within the bootstrapped confidence intervals at a confidence level of $90 \%$. 
Do Investors See the Darkness in Narcissism?

Appendix

CEO's Narcissism Manipulation.

Low CEO's narcissism condition

CEOs of fortune 500 companies, how narcissistic are they?

4- August 2018 - We recently collected data on CEO's degree of narcissism. Based on the data we collected from fortune $500 \mathrm{CEO}$ we were able to rank them from 1 (most narcissistic CEO) to 500 (least narcissistic CEO). The list below shares our ranking based on the data we collected.

1 -

2-

470- XYZ's CEO: David Egan

.

$500-$

High CEO's narcissism condition

CEOs of fortune 500 companies, how narcissistic are they?

4- August 2018 - We recently collected data on CEO's degree of narcissism. Based on the data we collected from fortune $500 \mathrm{CEO}$ s we were able to rank them from $\mathbf{l}$ (most narcissistic CEO) to $\mathbf{5 0 0}$ (least narcissistic CEO). The list below shares our ranking based on the data we collected.

1 -

2-

30- XYZ's CEO: David Egan

500- 